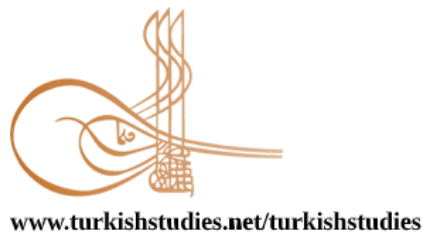

Turkish Studies

www.turkishstudies.net/turkishstudies

eISSN: $1308-2140$

BALKAN
UNIVERSTTY

Sponsored by IBU

Research Article / Araştırma Makalesi

\title{
COVID-19 Pandemisi Sürecinde Kaygı Öz-yeterlilik ve Psikolojik İyi Oluş Arasındaki İlişki: Özel Sektör ve Kamu Çalışanları Karşılaştırması
}

The Relationship Between Anxiety Self-efficacy and Psychological Well-Being during COVID-19 Pandemic Process: Comparison of Private and Public Sector Employees

\author{
Berat Çiçek* - Vedat Almalı*
}

\begin{abstract}
Covid-19 pandemic is the biggest epidemic of recent years, which has an effect all over the world. Pandemic has had a significant impact on people's social lives. Based on the fact that the pandemic will not only be limited to social life and may also affect the psychological status of individuals, this study aimed to investigate the effect of anxiety experienced during the Covid-19 pandemic process on psychological wellbeing and the role of emotional self-efficacy in the relationship between these variables. A survey was carried out for this purpose in Turkey. The research tools are approved by Mus Alparslan University, Scientific Research and Ethics Committee. The data obtained were analyzed by PLS structural equation modeling method. According to the results of the quantitative research conducted for public and private sector employees, pandemic anxiety affects psychological well-being negatively. Emotional self-efficacy also has a mediating role in this relationship. In other words, individuals with higher emotional self-efficacy have higher psychological well-being despite anxiety. According to the results of the multi-group analysis, the relationship between anxiety caused by Covid-19 pandemic and psychological well-being differs by sector. Accordingly, while the negative effect of pandemic anxiety on psychological well-being is negligible in public, this effect is much higher in the private sector. This research is original due to the following reasons. First, there are limited studies that examine these variables together in the literature. Second, there is a scale developed due to measuring pandemic anxiety. According to these originalities, the research is expected to contribute to the literature.
\end{abstract}

Structured Abstract: Purpose: The coronavirus disease 2019 (COVID-19) pandemic has become one of the central health crises of a generation. The pandemic has affected people of all nations, continents, races, and socioeconomic groups. The responses required, such as quarantining of entire communities, the closing of schools, social isolation, and shelter-in-place orders, have abruptly changed daily life (Shanafelt et al., 2020).

\footnotetext{
* Dr. Öğr. Üyesi, Muş Alparslan Üniversitesi, İ̈BF, İșletme Bölümü

Asst. Prof., Mus Alparslan University, Faculty of Economic and Administrative Sciences, Department of Business Administration

ORCID 0000-0002-4584-5862

beratcicek@gmail.com

${ }^{* *}$ Arş. Gör., Muş Alparslan Üniversitesi, İİBF, Siyaset Bilimi ve Kamu Yönetimi Bölümü

Research Assistant, Mus Alparslan University, Faculty of Economic and Administrative Sciences, Political Science and

Public Administration

ORCID 0000-0003-2124-703X

v.almali@alparslan.edu.tr

Cite as/ Atıf: Çiçek, B. \& Almalı, V. (2020). COVID-19 pandemisi sürecinde kaygı öz-yeterlilik ve psikolojik iyi oluş arasındaki ilişki: özel sektör ve kamu çalışanları karşıllaştırması. Turkish Studies, 15(4), 241-260. https://dx.doi.org/10.7827/TurkishStudies.43492

Received/Geliş: 11 May/Mayıs 2020

Accepted/Kabul: 10 August/Ağustos 2020

Copyright $(\mathrm{C}$ MDE, Turkey

Checked by plagiarism software

Published/Yayın: 30 August/Ağustos 2020

CC BY-NC 4.0
} 
Therefore, in this study, it was aimed to reveal the effects of anxiety caused by Covid-19 pandemic on the psychological well-being of employees and the role of emotional self-efficacy in this relationship.

\section{Method}

In order to test the model, cross-sectional research was designed, among other quantitative methods. Within this context, we tried to put forward the effect of anxiety caused by the Covid-19 pandemic on the wellbeing of employees and the mediating role of emotional self-efficacy in the relationship between these two variables. Partial Least Squares structural equation modeling (PLS-SEM) was employed (Ringle et al., 2015) to test the measurement and structural models. Wetzels et al., (2009:190) argued: "model complexity does not pose as severe a restriction to PLS path-modeling as to covariance-based SEM since PLS path-modeling at any moment only estimates a subset of parameters." Since this study is "predictive explanatory" according to the criteria of Henseler (2018), we utilized PLS-SEM as the method of analysis due to following three reasons: (1) to test a theoretical framework from a prediction perspective, (2) to examine increased complexity by exploring theoretical extensions of established theories (Hair et al. 2019), and (3) for mediation analysis (Hair et al. 2017). While SPSS 25 software was used to test normality, run exploratory factor analysis, and examine the potential for common method bias in our data, SmartPLS 3.3.2 software was employed to evaluate the measurement and structural models.

\section{Participants and Sampling}

The participants of this study have consisted of public and private sector employees from Turkey. The data was collected via an online data collection platform. Initially, 798 employees have participated in the surveys. However, 12 filled questionnaires were not evaluated as most of the items were not answered, or all items were answered with the same answer. Also, 8 of the responses were not taken into consideration because they constitute outliers in Mahalanobis and Cook's distance determination. Thus, we obtained 778 applicable questionnaires. $57,1 \%$ of participants are female, and $42,9 \%$ of participants are male. $29,3 \%$ of participants reported that they work in the public sector, while $16,7 \%$ of them work in the private sector, and $54 \%$ of them work as freelancer. The mean age of participants was 28,48 years, and the mean tenure was 4,69 years.

\section{Findings}

Before proceeding to the test of hypotheses, we established a measurement model to assess the construct reliability, convergent validity, and discriminant validity for first-order reflective variables (Hair et al. 2017). Our measurement model's reliability and convergent validity estimates are within the acceptable ranges. For the structural model and hypotheses testing, we used a bootstrapping procedure with 5000 iterations to assess the significance of the path coefficients. Finally, we run permutation-based multi-group analysis (Chin \& Dibbern, 2010) and Henseler's MGA (Henseler et al., 2009) to compare public and private sector employees.

First hypothesis of the study predicted that anxiety caused by the Covid-19 pandemic affects psychological well-being of employees negatively. H2 predicted that anxiety caused by Covid-19 pandemic affects emotional self-efficacy negatively. H3 predicted that emotional self-efficacy affects psychological wellbeing positively. $\mathrm{H} 4$ predicted that emotional self-efficacy mediates the relationship between anxiety caused by Covid-19 pandemic and psychological well-being. According to the analysis of the research, all four hypotheses were accepted.

We also test the effect of control variables such as gender, knowing Covid-19 patience, marital status, the number of children owned by the participants, and age on anxiety caused by the Covid-19 pandemic. The results of the structural analysis illustrate that gender has a significant effect on anxiety caused by the Covid19 pandemic while knowing Covid-19 patience, marital status, the number of children owned by the participants, and age don't have a significant effect.

According to the results of the multi-group analysis, the relationship between anxiety caused by Covid-19 pandemic and psychological well-being differs by sector. Accordingly, while the negative effect of pandemic anxiety on psychological well-being is negligible in public, this effect is much higher in the private sector. In other words, pandemic anxiety has shaken private sector employees more. It was determined that there was no significant difference among other variables, according to the sector.

Keywords: Organizational Psychology, Covid-19, Anxiety, Psychological Well-being, Self-Efficacy, PLS 
Öz: Covid-19 pandemisi tüm dünyada etkisini gösteren son yılların en büyük salgın hastalığıdır. Pandemi, insanların sosyal hayatlarına önemli ölçüde etki etmiş̧tir. Pandeminin sadece sosyal hayatla sınırlı olmayacağı ve bireylerin psikolojik durumlarına da etki edebileceği gerçeğinden hareketle bu çalışmada Covid-19 pandemisi sürecinde yaşanan kaygının psikolojik iyi oluşa etkisi ve bu değişkenler arasındaki ilişkide duygusal öz-yeterliliğin rolünün araştırılması amaçlanmıştır. Bu amaç doğrultusunda Türkiye genelinde bir anket çalışması gerçekleştirilmiştir. Araştırma için, Muş Alparslan Üniversitesi, Bilimsel Araştırma ve Etik Kurulundan etik kurul onayı alınmıştır. Elde edilen veriler kısmi en küçük kareler (Partial Least Squares - PLS) yapısal eşitlik modellemesi metoduyla analiz edilmiştir. Kamu ve özel sektör çalışanları özelinde gerçekleştirilen nicel araştırmanın sonuçlarına göre pandemik kaygı psikolojik iyi oluşu olumsuz etkilemektedir. Ayrıca duygusal öz-yeterlilik bu ilişkide aracı rol üstlenmektedir. Başka bir deyişle duygusal öz yeterliliği yüksek bireylerin kaygıya rağmen psikolojik iyi oluşları daha yüksek seviyededir. Çoklu grup analizi sonuçlarına göre ise Covid-19 salgınının neden olduğu kaygı ile psikolojik iyi oluş arasındaki ilişki sektöre göre değişmektedir. Buna göre, pandemik anksiyetenin psikolojik iyi oluş üzerindeki olumsuz etkisi kamuoyunda anlamsıza yakın olmakla birlikte, bu etki özel sektörde çok daha yüksektir. Araştırma, bu değişkenleri bir arada inceleyen kısıtlı çalışmalardan biri olması ve pandemik kaygıyı ölçmeye yönelik bir ölçek geliştirilmiş olması yönleriyle özgün bir çalışmadır ve böylece literatüre katkı sunması beklenmektedir.

Anahtar Kelimeler: Örgütsel Psikoloji, Covid-19, Kaygı, Psikolojik İyi Oluş, Öz-Yeterlilik, PLS

\section{Giriş}

Korona virüs hastalığı 2019 (Covid-19) pandemisi, neslimizin en önemli hastalığı haline gelmiş̧tir. Yaşadığımız bu salgın hemen hemen tüm uluslar, kıtalar, ırklar ve sosyoekonomik gruplardan insanları etkilemiş durumdadır. Tüm toplulukların karantinaya alınması, okulların kapatılması, sosyal izolasyon ve yerinde barınma emirleri gibi önlemler nedeniyle günlük yaşam aniden değişmiş̧tir (Shanafelt vd., 2020).

Günümüz toplumlarında yaşam, artan küresel bağımlılık kadar hızlandırılmış sosyal ve teknolojik değişimden geçmektedir. Bu zorlu yeni gerçekler, insanların yaşamları boyunca bir miktar kontrol kullanma yetenekleri üzerinde ağır baskı oluşturmaktadır. İnsanların yaşam taleplerini yönetmek için kişisel etkinliklerine olan inançları psikolojik iyi oluşlarını, başarılarını ve yaşamlarının yönünü etkilemektedir. Eylemleri başlatan inançlar, bu eylemlere ve onların sonuçlarına da dayanmaktadır (Maloney, 1990). Kritik olaylarda olduğu gibi (kazalar, kayıplar, boşanma, hastalık vb.) Ortaya çıkan psikolojik kriz kişilik gelişimi, psikososyal işlevsellik ve iyi oluş üzerinde derin bir etkiye sahip olabilmektedir.

Stres faktörleri, kaynaklar, güvenlik açıkları ve kısıtlamalarla karşılaşmak stres değerlendirmelerini, baş etme stratejilerini ve öznel iyi oluşu etkilemektedir (Jerusalem ve Mittag, 1995). Bireyin bilişsel ve kişilik kaynaklarını seferber edebilmesi en önemli psikolojik mekanizmadır (Morosanova, vd., 2019). Hemen hemen her davranışın yerine getirilmesi, davranmamaktan daha fazla çaba gerektirmektedir. Davranıştan kaçınmak, kişinin baskın tepkilerini önlemek için kendi davranış kalıplarını değiştirdiği bir öz kontrol eylemi gerektirmektedir (Muraven ve Baumeister. 2000).

Covid-19 aynı anda birçok insanın normal yaşamını olumsuz etkilediği ve içerisinde birçok belirsizlik barındırdığı için kaygıya neden olmaktadır. Virüsün yayılma hızı ve insandan insana bulaşma hızı bireysel ilişkiler üzerinde de baskı oluşturmaktadır. Salgının ne kadar süreceği ve kötüye gideceği hakkında yeterli bilgiler olmadığı için ortaya çıkan belirsizlikte kaygıyı artırmaktadır. Pandemi döneminde her gün stresli ve kaygılı hissetme hali psikolojik iyi oluş üzerinde de olumsuz etkilere sebep olabilecektir.

Buradan hareketle bu çalışmada Covid-19 pandemisi nedeniyle oluşan kaygının çalışanların iyi oluşlarına etkisi ve bu ilişkide duygusal öz-yeterliliğin rolünün ortaya konulması amaçlanmıştır. $\mathrm{Bu}$ amaç doğrultusunda nedensel tarama desenine dayalı nicel bir araştırma gerçekleştirilmiştir. 
Türkiye genelindeki çalışanlardan online anket yöntemiyle toplanan veriler analiz edilmiştir. Çalışmanın, gerek özgün bir ölçek geliştirilmesi yönüyle gerekse de pandeminin psikolojik yönüne ve çalışan/çalışmak zorunda olan bireyleri odağa alması nedeniyle Covid-19 literatüründeki boşluğu doldurmaya yardımcı olması beklenmektedir.

\section{Literatür Taraması}

\subsection{Kaygı}

Kaygı, bilişsel bir bileşen, açıklanması zor veya rahatsız edici durumların anlaşılması olarak ifade edilmektedir (Morosanova vd., 2019), ayrıca duygusal bir durum olarak kabul edilir ve stres ile açık benzerlikleri vardır (Lovibond \& Lovibond, 1995). Amerikan Psikoloji Derneği (APA, 2020) kaygıy1 "gerginlik hissi, endişeli düşünceler ve fiziksel değişiklikler (artan kan basınc1 gibi) ile ortaya çıkan bir duygu" olarak tanımlamaktadır. Bu bakımdan kaygının belirtileri şöyle sıralanabilir: Huzursuzluk, kontrol edilemeyen endişe, sinirli bir hal ve motivasyonda yaşanan zorluklar. Motivasyonun niteliğini kişilerin duygusal tepkileri belirlemektedir. Öz-yeterliliğin düşük olması durumunda, kaygı gibi olumsuz etkiler ortaya çıkmakta ve motivasyonu olumsuz etkilemektedir. $\mathrm{Bu}$ etki; çaresizlik, kaçınma veya geri çekilme şeklinde kendini göstermektedir (Zimmerman, 1989b).

Kayg1, özellikle tehdidin doğası iyi anlaşılmadığında, ortaya çıkışı belirsiz olduğunda ve bireyler kendilerini stresin başlangıcı veya sonlandırması üzerinde çok az kontrole sahip olarak hissettiklerinde bariz bir sıkıntı kaynağı olmaktadır. Bireyin belirsiz olaylarla başa çıkma eğilimi ve yöntemleri de dâhil olmak üzere, pandemilerin yarattığı tehditlerin kaygıyı arttıracağı yönünde çok sayıda psikososyal faktörün olduğu belirtilmiştir (Taha vd., 2013).

Kaygının eylem kontrol süreçlerini olumsuz yönde etkilediğine dair çalışmalar mevcuttur. Kayg1 ve düşük öz-yeterlik algıları kişilerin üst bilişsel kontrol süreçlerinin kullanımını zayiflatabilmekte ve uzun vadeli hedeflerin belirlenmesini engelleyebilmektedir (Zimmerman, 1989a). Olumlu duygusal durum kişilerin öz-yeterlilik algılarını artırırken, kayg1 ve ümitsizliğin ise öz-yeterlilik algısını düşürdüğü öne sürülmektedir (Bandura, 1994).

De Beurs vd. (1999) yapmış oldukları çalışmada, kaygının yaşlı bireylerin hareketleri ve iyi oluşları üzerinde net bir olumsuz etkisi olduğu sonucuna varmıştır. Taha vd. (2013) yaptıkları çalışmada, erkeklerin kadınlara göre kaygı ve stres yönetiminde daha başarılı oldukları sonucuna ulaşmıştır. Öğrenciler üzerinde yapılan bir çalışmada ise yüksek sınav kaygısına sahip olan öğrencilerin sınav sonuçlarının daha kötü olduğu sonucuna varılmıştır (Morosanova vd., 2019). Bu bağlamda kaygı kişilerin yaşam şekilleri ve kendileri için önemli sayılabilecek olaylar (sınavlar, iş hayatı vb.) üzerinde ciddi olumsuz sonuçlar yaratabilmektedir.

Sağlık kaygısının yapısı üzerine de farklı araştırmalara rastlamak mümkündür. Hastalanma olasılı̆̆ının şişirilmiş tahminlerinden ve ciddi bir hastalığa sahip olmanın olumsuz sonuçlarının abartılı bir algısından oluştuğu belirtilmiştir. Sağlık kaygısı, korkulan bir hastalığın ne kadar muhtemel ve ne kadar şiddetli olduğunun algılanmasının bir fonksiyonudur. Pandemi dönemlerinde psikolojik faktörlerin kaygı ile ilişkili olduğunu gösteren bulgular vardır (Wheaton vd., 2011). Salgın sırasında hastanede yatan çocukların ebeveynlerinin ruh sağlığı sorunlarının daha ciddi olduğu, kaygı ve depresyonun daha belirgin olduğu görülmüsstür (Yuan vd., 2020).

Bir pandeminin medyada (sosyal, görsel, yazılı) sürekli olarak yer alması potansiyel olarak kitle histerisi ve korkusuna yol açabilir, ayrıca yoğun televizyon maruziyetinin bu hastalıktan daha büyük korku ve kaygı ile ilişkili olduğu belirtilmiştir (Wheaton vd., 2011). Bu kapsamda sadece viral tehditlerle ilgili belirsiz tahminler sağlayan bilgileri edinmek, belirsizlik algılarına ve dolayısıyla kaygıyı artırmaya hizmet edebilir (Taha vd., 2013). 


\subsection{Psikolojik İyi Oluş}

Bradburn (1969) psikolojik iyi oluşu, "olumlu duyguların daha fazla, olumsuz duyguların ise daha az yaşanması" olarak tanımlamaktadır (Akt. Akdağ ve Çankaya, 2015: 647). Farklı araştırmacılar psikolojik iyi oluş için farklı tanımlar kullanmaktadır. Bazıları psikolojik iyi oluşu, yaşam doyumunu refahın temel göstergesi olarak vurgulayan bilişsel bir süreç olarak tanımlamaktadır (Kammann ve Flett, 1983). Martin ve Rubin (1995) ise fiziksel süreçleri vurgulamak ve fiziksel sağlık ile yüksek yaşam kalitesi arasındaki bağlantıya vurgu yapmaktadır. Olumlu özsaygı ve kendine hâkim olma, başkalarıyla kaliteli ve anlamlı bağlantılara sahip olma gibi öz ve sosyal süreçler (Ellison, 1983; Goldberg ve Hillier, 1979), bireyin gelişimi ve kendini gerçekleştirmesiyle ilgilidir (Ryff ve Singer, 2008). Sonuç olarak, psikolojik iyi oluş duygusal, fiziksel, bilişsel, manevi ve sosyal süreçlere atıfta bulunularak ifade edilmektedir (Roothman vd., 2003).

İyi oluşun farklı boyutları tartışılsa da genel kalitesi optimal psikolojik işlevsellik ve deneyime işaret eder. İyi oluşu (refah) açıklamak için tarihsel olarak iki geniş psikolojik gelenek öne çıkmaktadır. Hedonik görüş, iyi oluşu mutlulukla eşitlemekte, genellikle olumlu ve olumsuz etkiler arasındaki denge olarak açıklamaktadır. Hedonik görüsse göre mutluluk, zevkin varlığı ve acının olmaması olarak ifade edilebilir (Shin ve Johnson, 1978). Öte yandan, eudaimonik bakış açısı, insanların gerçek benliklerine göre ne kadar iyi yaşadıklarını değerlendirmektedir (Springer ve Hauser, 2006).

Kişinin ve geçmiş yaşamının olumlu değerlendirmelerini (öz kabul), bir kişi olarak sürekli büyüme ve gelişme hissini (kişisel büyüme), kişinin hayatının amaçlı ve anlamlı olduğu inancını (hayattaki amaç), başkalarıyla kalite ilişkilerine sahip olmayı (diğerleriyle olumlu ilişkiler), kişinin hayatını ve çevresindeki dünyayı etkin bir şekilde yönetme kapasitesini (çevresel hâkimiyet) ve kendi kaderini tayin duygusu (özerklik) psikolojik iyi oluşun bileşenleri olarak ifade edilebilir (Ryff, 1989; Ryff ve Keyes, 1995). Görüldüğü üzere psikolojik iyi oluş sıkıntı ve diğer zihinsel problemlerden arınmış olmaktan daha fazlasını içermektedir (Ryff, 1995).

İyi oluş üç temel ihtiyaç türünün tatminine bağlıdır. Bunlar, sahip olma ihtiyacı, ilişki kurma ihtiyacı ve varlık ihtiyacıdır. Sahip olma ihtiyacı; maddi ihtiyaçların ve ilgili kişisel olmayan kaynakların edinilmesini ifade etmektedir. Illişki kurma ihtiyacı, sosyal ilişkilere işaret etmektedir. Varlık ihtiyacı ise kişinin kendisinden memnun olma duygusu ile ilgilidir. Kendini gerçekleştirme ve öz-yeterlilik duyguları, kişinin yaşamı üzerindeki yönü ve değeri ile ilişkilidir (Ellison, 1983).

Birçok araştırma, psikolojik iyi oluştaki farkl1lıkları açıklamak için, eğitim, yaş, medeni ve ebeveynlik durumu, deneyimler, çocuk sahibi olmak, mesleki başarılar ve deneyimler, sağlık sorunları gibi geniş sosyo-demografik faktörler kullanmıştır. Bu deneyimler yaşam seyrindeki konumlarına, ortaya çıkan zorluğun veya görevin doğasına göre değişir (Ryff, 1995). Ryff ve Keyes (1995) yapmış olduğu çalışmada, pozitif ilişkiler ve kişisel büyüme konusunda kadınların erkeklerden önemli ölçüde daha yüksek puan aldıklarını belirlemişlerdir. Ayrıca psikolojik iyi oluş bakımından cinsiyet farklılıklarını açıklamışlardır. Çok sayıda çalışma ailenin ve özellikle evliliğin, yaşam doyumu, psikolojik iyi oluş, zihinsel ve fiziksel sağlık açısından belirleyici bir etkisi olduğunu ortaya koymuştur (Gove vd., 1983). Ebeveynleri tarafından sevgi, kabul ve destek sağlanan küçük çocukların ve ergenlerin daha yüksek benlik saygısı, daha düşük kaygı ve depresyon düzeyine sahip olduğu, daha fazla mutluluk ve başarı ve daha az davranışsal sorun bildirdiklerini göstermektedir. Genç yaşlarında ebeveyn-çocuk sevgisinin keyfini çıkaran genç yetişkinler, 14 yıl sonra daha fazla psikolojik iyi oluşu öngören daha yüksek özgüven bildirmişlerdir (Roberts ve Bengtson, 1993). Ayrıca Rogers ve DeBoer (2001) yaptıkları çalışmalarında evli kadınların mutlak ve göreceli olarak gelirlerindeki artışların evlilikteki mutluluklarını ve psikolojik iyi oluşlarını önemli ölçüde artırdığını belirtmişlerdir. Gene aynı çalışmada gelir ve istihdamın hem kadınların hem de erkeklerin psikolojik iyi oluşları üzerinde yararlı etkileri olduğu belirtilmiştir. 
Çin menşeli yeni Covid-19, sınırları hızla aşarak tüm dünyadaki insanları etkilemektedir. Kitle iletişim araçlarının yaygınlığı ve etkinliği sayesinde kişiler pandemi hakkında her şeyi sınırlar ötesinden sürekli takip edebilmektedir. Bütün bunlar yüksek kaygı düzeylerine sahip insanlar için olumsuz durumlar yaratmaktadır çünkü salgınlar kaygı ve stresin artmasına neden olmaktadır (Roy vd., 2020). Pandemi dönemlerinde en çok kaygı duyulan alanlar: idari organizasyonlara karş1 güvensizlik, tıbbi hizmetlere güvensizlik ve sorunlarla başa çıkmada kendine güvensizlik şeklindedir (Yamazaki ve Kikkawa, 2010). Bu çalışmalardan hareketle araştırmada test edilmek üzere aşağıdaki hipotez geliştirilmiştir.

\section{H1: Covid-19 anksiyetesi psikolojik iyi oluşu olumsuz yönde etkilemektedir.}

\subsection{Duygusal Öz-Yeterlilik}

Son zamanlarda psikologlar insanların kendi davranışlarını ne ölçüde etkilediğine, değiştirdiğine veya kontrol edebildiğine odaklanmıştır (Baumeister ve Heatherton, 1996). Özyeterlilik kavramı da bu noktada karşımıza çıkmaktadır. Algılanan öz-yeterlik, kişinin olası durumları yönetmek için gereken eylem yollarını organize etme ve yürütme yeteneklerine olan inançları ifade etmektedir.

Pozitif ruh hali algılanan öz-yeterliliği arttırırken, umutsuz ruh hali ise azaltmaktadır (Bandura, 1995). Bununla birlikte, öz kontrol gücünün kaybedilmesi, bir hedefe ulaşma algısını etkileyebilir. Başka bir deyişle, tükenme öz-yeterlik duygularını azaltabilir (Bandura, 1977; Muraven ve Baumeister. 2000). Kişilerin öz-yeterliliğe olan inançları yaşam seçimlerini, motivasyon seviyesini, işleyiş kalitesini, sıkıntıya karşı dayanıklılığı, stres ve depresyona karşı savunmasızlığ 1 etkilemektedir (Bandura, 1994). Öz-yeterlilik, alana özgü veya duruma özgü bir biliş olarak değil, farklı çevresel talep türlerini yönetme kabiliyetine özgü bir genel güven duygusu olarak ifade edilebilir (Jerusalem ve Mittag, 1995). Chen vd. (2004) öz-yeterliliği motivasyon ile yakından ilişkili bir kavram olarak açıklamaktadırlar. Kirk vd. (2008) ise öz-yeterliliği, bir kişinin belirli bir kazanım elde etmek için gereken eylem planlarını organize etme ve yürütme becerilerine olan inançları olarak ifade etmektedirler. Zimmerman (1989a), kişinin karşılaştı̆g belirli durumlarda gerekli eylemleri organize etme ve uygulama yeteneği hakkındaki algıları olarak ifade etmektedir.

Öz-yeterlik inançları, değerlendirme süreçlerini etkileyen ve sonuç olarak eylemleri yönlendiren ve birbirine bağlı bilgi yapılarını yansıtmaktadır (Bandura, 1977; Caprara vd., 2008; Çiçek ve Karakaş, 2020). Öz-yeterlik inançları insanların kendilerini nasıl hissettiklerini, düşündüklerini, motive ettiklerini ve davrandıklarını belirler. Bu tür inançlar dört ana süreç aracılığıyla bu çeşitli etkileri ortaya çıkarmaktadır. Bilişsel, motivasyonel, duygusal ve seçim süreçlerini içerir (Bandura, 1994). Öz-yeterlik inançlarının, özdenetim sürecinin inşasında merkezi bir rol oynamaktadır. Bunlar "öz gözlem”, “öz yargı” ve "öz tepkiler” üzerindeki etkiler de karşımıza çıkmaktadır (Zimmerman, 1989a). Öz-yeterliliğin kaynakları ise kişisel deneyimler, dolaylı yollardan elde edilen tecrübeler, başkaları tarafından onaylanma ve fiziksel ve duygusal durumdur (Bandura, 1977; Bandura, 1995).

Belirli alanlarda etki duygusu düşük olan insanlar, kişisel tehditler olarak gördükleri zor görevlerden uzak dururlar ve hedeflere bağl1lıkları zayıftır. Zor görevlerle karşı karşıya kaldıklarında, kişisel eksiklikleri, karşılaşacakları engeller ve nasıl başarılı performans göstereceklerine odaklanmak yerine her türlü olumsuz sonuç üzerinde dururlar zorluklar karşısında hızla pes etmektedirler. Başarısızlık veya aksaklıklardan sonra öz-yeterlilik duygularını geri kazanmaları yavaştır. Yetersiz performansı yetersiz yetenek olarak gördüklerinden, yeteneklerine olan inançlarını kaybetmeleri için fazla başarısızlık gerekmez çünkü stres ve depresyona karşı yenilirler (Bandura, 1995: 11; Işık ve Çiçek, 2020). Stres veya yorgunluk bireyin gücünü tükettiğinde, başarısızlıklar daha olası hale gelir (Baumeister ve Heatherton, 1996; Çiçek ve Kılınç, 2020). Düşük öz-yeterliğe sebep olan durumlardan bir tanesi de kendi kendine memnuniyetsizliktir, 
bu da öğrenme ve güçlüklerle başa çıkabilme çabalarını olumsuz etkileyecektir (Zimmerman, 2002). $\mathrm{Bu}$ tanımlamalardan hareketle aşağıdaki hipotez kurulmuştur.

\section{H2: Covid-19 anksiyetesi duygusal öz-yeterliliği olumsuz yönde etkilemektedir.}

Yüksek algılanan öz-yeterlilik hissine sahip insanlar, farklı çevresel tepkileri yönetme yeteneklerine güvenmektedir. Yüksek algılanan öz-yeterlilik, bireylerin stresli taleplerle güvenle yüzleşmelerini, fizyolojik uyarılma ile motive hissetmelerini ve öncelikle dış koşullardan kaynaklanan çaba ve olumsuz olayların neden olduğu olumlu olayları yönetebilmelerini sağlar. Buna karşılık, düşük algılanan etkinlik ile karakterize edilen bireyler, kendinden şüphe duyma, kaygı, zor durumlarla ve taleplerle karşı karşıya kaldıklarında baş etme eksikliklerine karşı algılara eğilimlidir (Jerusalem ve Mittag, 1995). Algılanan öz-yeterlilik bağımlılık davranışları alanında benzersiz bir rol oynamaktadır. Bu inançlar hem bağımlılık alışkanlıklarının ilk gelişimini hem de bu alışkanlıkların sona ermesini ve yoksunluğun sürdürülmesini içeren davranış değişikliği sürecini etkiler (Marlat vd., 1995). Algılanan öz-yeterlilik ne kadar güçlü olursa, sorunlar karşısında gösterilen çabalar da o kadar aktif olmaktadır (Bandura, 1977). Bu çalışmalardan hareketle araştırmada test edilmek üzere aşağıdaki hipotez geliştirilmiştir.

\section{H3: Duygusal öz-yeterlilik psikolojik iyi oluşu pozitif yönde etkilemektedir.}

Öz-yeterlilik noktasında yapılan ampirik çalışmalarda farklı sonuçlar ile karşılaşılmaktadır. Zimmerman (1995), yapmış olduğu çalışmasında, eğitimsel bir görevi yerine getirmede yüksek bir öz-yeterlilik duygusu olan öğrencilerin, zorluklarla karşılaştıklarında yeteneklerinden şüphe duyanlardan daha kolay katılım sağladığı, daha fazla çalıştığı ve daha uzun süre devam ettiği sonucuna varmıştır. Bandura (1977), öz-yeterliliğin performansın yordayıcısı olduğunu belirtmiş ve çalışmasında katılımcılar gelecekteki performanslarını geçmiş davranışları üzerinde değerlendirdiklerini belirtmişlerdir.

Yüksek duygusal öz-yeterlik, daha fazla duygusal duygusal zekâ, daha yüksek performans, daha yüksek olumlu ruh hali ve daha düşük olumsuz ruh hali ile ilişkili (Kirk, vd., 2008) bir kavramdır. Sonuç olarak, herhangi bir durumda, bir kişi nasıl davranacağı konusunda seçeneklere sahiptir. İnsanlar bir değişiklik yapmaya başlamadan önce, uyum sağlamak veya değişim için bir nedene veya güce ihtiyaç duymaktadırlar. Bilişsel olarak esnek insanlar da etkili bir şekilde davranma yeteneklerinden emindirler. Her ne kadar insanlar belirli bir durumda alternatif davranış seçenekleri olduğunu ve esnek olmaya istekli olduklarının farkında olsalar da istenen davranışı ortaya çıarmada öz-yeterliliğe sahip olduklarına inanmaları gerekmektedir (Martin ve Rubin, 1995). Buradan hareketle araştırmada test edilmek üzere aşağıdaki hipotez geliştirilmiştir.

H4: Duygusal öz-yeterlilik, Covid-19 anksiyetesi ile psikolojik iyi oluş arasındaki ilişkide aract role sahiptir.

\section{Yöntem}

Bu araştırmada pandemik kaygının psikolojik iyi oluşa etkisi ve bu iki değişken arasındaki ilişkide duygusal öz-yeterliliğin rolünün ortaya konulması amaçlanmıştır. Bu amaç doğrultusunda nedensel tarama desenine göre dizayn edilmiş nicel bir araştırma gerçekleştirilmiştir. Araştırma için, Muş Alparslan Üniversitesi, Bilimsel Araştırma ve Etik Kurulundan 29/04/2020 tarihli ve 5 nolu toplantıda 12 numaralı karar ile etik kurul onayı alınmıştır. Elde edilen veriler yapısal eşitlik modellemesi (YEM) yaklaşımına göre analiz edilmiştir. YEM, sosyal bilimler ve davranış bilimleri içindeki teorik modelleri açıklamada yaygın olarak kullanılan bir yöntemdir (Quintana ve Maxwell, 1999; Martens, 2005; Weston ve Gore, 2006). Yapısal eşitlik modellemesinde iki temel yaklaşım mevcuttur. Bunlar: kovaryans temelli YEM ve kısmi en küçük kareler (Partial Least Squares - PLS) yöntemidir. Bu çalışmada PLS-YEM tercih edilmiştir (Ringle vd., 2015). PLS yöntemi, hesaplama yaparken her defasında yalnızca sadece bir parametre alt kümesini tahmin ettiğinden, daha karmaşık 
modelleri hesaplamada kovaryans temelli yaklaşımlara göre daha başarılıdır (Wetzels vd., 2009). Ayrıca, parametrik olmayan ve literatürde daha önce benzeri olmayan çalışmaları test etmede (Henseler, 2018), yerleşik teorilerin teorik uzantılarını araştırarak artan karmaşıklığı incelemede (Hair vd., 2019) ve aracılık analizinde (Hair vd., 2017) başarılı bir yöntem olduğu için bu çalışmada PLS-YEM tercih edilmiştir. Bu bağlamda verilerin normallik dağılımını, aykırı değerleri, faktör analizini ve ortak yöntem varyansı hatalarını tespit etmede SPSS v26 programından yararlanılmıştır. Ölçüm modeli ve yapısal modeli test etmek için ise SmartPLS v3.3.2 programı kullanılmıştır. Araştırmada test edilmek üzere oluşturulan model ve hipotezler Şekil 1'de verilmiştir.

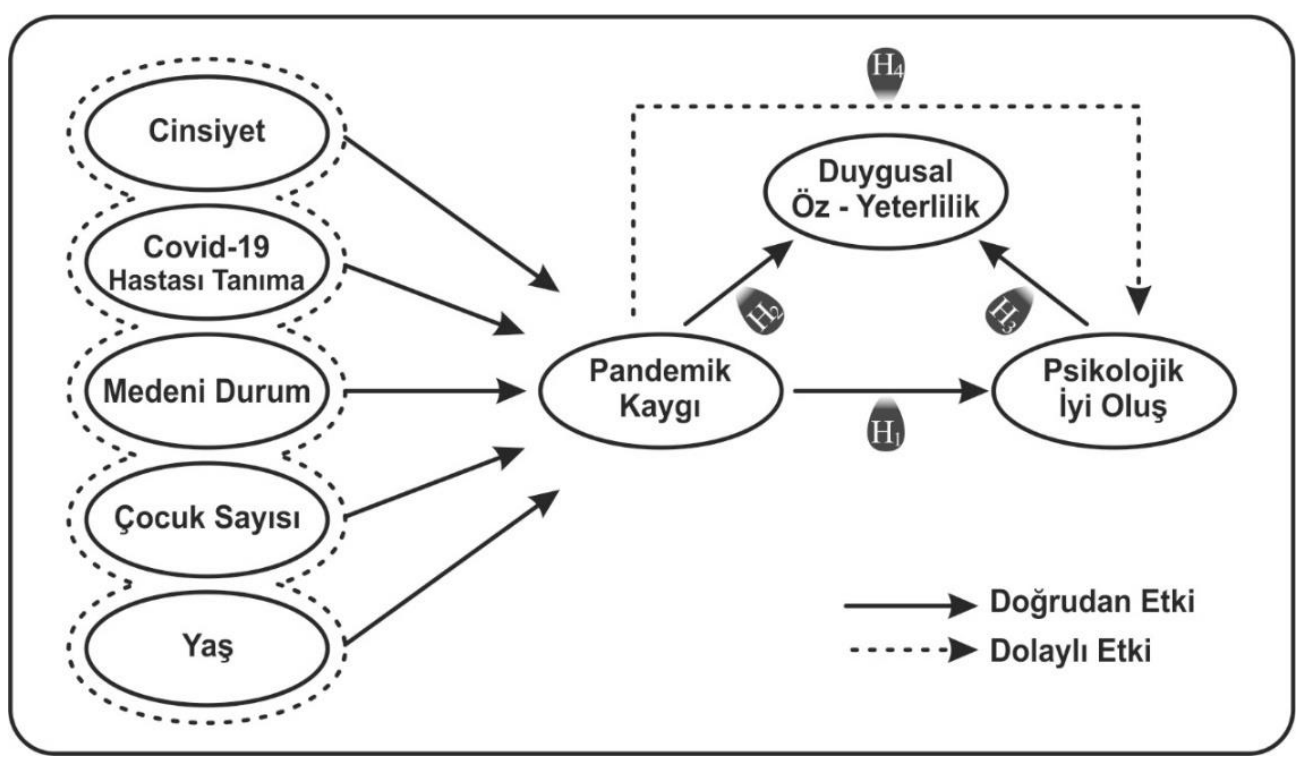

Şekil 1. Araştırma Modeli

\subsection{Katılımcılar ve Ölçüm Araçları}

Araştırmanın anakütlesini Türkiye'deki çalışanlar ve pandemi sürecinde işini kaybedenler oluşturmuştur. Anakütlenin tümüne ulaşmak mümkün olmadığından örnekleme yapılmıştır. Örnekleme yöntemi olarak amaçlı örnekleme yaklaşımı tercih edilmiştir. Bu yaklaşımın seçilmesinin temel sebebi katılımcıların bilgi açısından zengin oldukları varsayımıdır (Easterby-Smith vd., 2012). Amaçlı örnekleme türlerinden ise maksimum çeşitlilik türü tercih edilmiştir. Böylece sektör fark1 gözetmeksizin geniş kitlelere ulaşılmıştır.

Veri toplamak amacıyla Google Formlar platformu kullanılarak çevrimiçi bir anket hazırlanmıştır. Pandemi sürecinde sosyal mesafeyi koruyabilmek adına bu yöntem tercih edilmiştir. Anket sosyal ağlar aracılığıyla katılımcılara iletilmiştir. Dört bölümden oluşan anket formunun başında çalışmanın niteliğini, gizlilik konularını ve katılımın gönüllü olduğunu belirten bir onam sayfası yer almıştır. İlk bölümde katılımcıların demografik bilgilerini öğrenmeye yönelik sorular yöneltilmiştir. Ankete toplamda 798 kişi katılmıştır. Fakat anketlerden 12 tanesi ifadelerin çoğu cevaplanmadığı veya cevapların tümü aynı olduğu için, 8 tanesi ise yapılan testlerde (Mahalanobis, Cook's distance) aykırı değer olarak tespit edildiği için değerlendirmeye alınmamıştır. Böylece 778 anket değerlendirilmiştir. Buna göre katılımcıların \%57,1'i kadın, 42,9'u erkektir; \%59,4'ü bekar, 39,1'i evli, \%1,6'sı ise medeni durumu diğer olarak işaretlemiştir; \%29,3'ü kamuda çalışmakta iken, 16,7'si özel sektörde çalışmaktadır, \%54'ü ise son işinde serbest çalıştığını belirtmiştir. Katılımcıların \%62'si çocuk sahibi değilken, \%12,5'i 1, \%11,8'i 2, \%8,1'i 3, \%5,7'si ise 4 veya daha fazla çocuk sahibidir. Ankete katılanların \%25,8'i covid-19 salgınına yakalanan birini şahsen tanırken, $\% 74,1$ 'i virüse yakalanan birini şahsen tanımamaktadır. Ayrıca anketi cevaplayanların yaş ortalaması 28,48; son işlerinde çalışma süreleri ise ortalama 4,69 yıldır. 
Anketin ikinci kısmında araştırmacılar tarafından geliştirilen ve pandemik kaygıyı ölçmeye yönelik 9 ifadeden oluşan ölçek yer almıştır. Ölçeğin örnek maddeleri: "Korona virüse yakalanmaktan kaygı duyuyorum" ve "Aileme ve sevdiklerime korona virüs bulaşması ihtimali beni endişelendiriyor" şeklindedir. Nihai testlere geçilmeden önce bu ölçek için keşfedici faktör analizi yapılmıştır. Yapılan analiz sonucunda ölçeğin tek boyutlu bir yapıya büründüğg̈, maddelerin 0,50 'nin üzerinde faktör yüklerine sahip olduğu ve ölçek maddeleri arasında yüksek korelasyon değerleri sağlandığı görülmüsstür. Ayrıca yapılan doğrulayıcı faktör analizinde ölçeğin uyum indekslerinin oldukça iyi olduğu görülmüştür. Ölçek maddeleri çalışmanın ekinde paylaşılmıştır.

Üçüncü kısımda Qualter vd. (2015) tarafından geliştirilen duygusal öz-yeterlilik ölçeğinin 10 maddeden oluşan ve araştırmanın amacına uygun olduğu tespit edilen "duygularını kullanma ve yönetme" boyutu adapte edilmiştir. Ölçeği geliştiren araştırmacılar tarafından güvenirliği a $=0,89$ olarak ölçülen ölçeğin örnek maddeleri: "Mutsuz olduğum zaman kendimi nasıl mutlu edeceğimi bilirim" ve "Stresliyken duygularımı nasıl kontrol edeceğimi bilirim" şeklindedir.

Anketin son kısmında ise Diener vd. (2009) tarafından geliştirilen psikolojik iyi oluş ölçeği kullanılmıştır. 8 maddeden oluşan ölçeğin güvenirliği ölçeği geliştiren araştırmacılar tarafından $a=$ 0,86 olarak ölçülmüştür. Ölçeğin örnek maddeleri: "Başkalarının mutluluğuna ve kendilerini iyi hissetmelerine aktif olarak katkıda bulunurum" ve "Geleceğim hakkında iyimserim"dir.

Brislin (1980) tarafindan önerilen paralel kör teknikle Türkçeye çevrilen ölçeklerin tümü Likert tipindedir ve 7 aralıktan oluşmuştur. Ölçek aralıkları pandemik kaygı ve psikolojik iyi oluş ölçekleri için "1 = Hiç katılmıyorum" ve "7 = Tamamen katılıyorum" şeklinde kodlanmıştır. Duygusal öz-yeterlilik ölçeği için ise "1 = Hiçbir zaman" ve "7 = Her zaman" şeklinde kodlanmıştır.

Ölçeklerin dışında değişkenleri etkileyeceği düşünülen cinsiyet, yaş, medeni durum, Covid19'a yakalanmış hasta tanıma, sahip olunan çocuk sayısı ve çalışılan sektör değişkenleri araştırmada kontrol değişkenler olarak test edilmiştir.

Tüm çalışan ve yöneticilerden aynı anda veri toplandığı için ortak yöntem varyansı problem yaratabilmektedir. Ortak yöntem varyansı, yapıların kendisinden ziyade paylaşılan ölçüm yöntemlerine dayandırılabilecek varyansa atıfta bulunmakta ve bu durum ölçüm hatalarına neden olabilmektedir (Podsakoff vd., 2003). Ortak yöntem varyansını test etmek için öncelikle Harman'ın (1967) tek-faktör testi uygulanmıştır. Buna göre döndürme uygulamadan tüm maddeler tek faktör altında faktör analizine tabi tutulmuştur. Yapılan analiz sonucunda tüm maddelerin toplam varyansı açıklama yüzdesi \%50'nin oldukça altında $(\% 29,9)$ olduğu için bu yönteme göre ortak yöntem varyans hatası olmadığı sonucuna ulaşılmıştır (Kline, 2005). Daha sonra Kock (2015) tarafından PLS-YEM için potansiyel ortak yöntem yanlılığını ortaya koymaya yönelik tavsiye edilen tam doğrudaşlık yöntemi uygulanmıştır. Buna göre maddelerin VIF değerlerinin 3,3'ün altında olması gerekmektedir. Ölçüm modelindeki en büyük VIF değeri 2,883 olduğundan ortak yöntem varyansının bu çalışmada sorun teşkil etmediği sonucuna ulaşılmıştır.

\subsection{Bulgular}

\subsection{1. Ölçüm Modeli}

Hipotezleri test etme adımına geçmeden önce yapı geçerliliğini ve güvenilirliğini, uyuşum ve ayrışım geçerliliklerini test etmek amacıyla ölçüm modeli kurulmuştur (Hair vd., 2017). Bu bağlamda öncelikle ölçek maddelerinin faktör yükleri kontrol edilmiştir. Hair vd.'ne göre (2017) PLS tabanlı ölçüm modelindeki her maddenin dış yükleme değerleri 0,708 eşiğinin üzerinde olmalıdır çünkü bu sayının karesi klasik faktör yükündeki 0,50 eşiğine eşittir $\left(0,708^{2}=0,50\right)$. Bu değerin altında olan dış yükleme değerleri ise iyi geçerlilik oranları yakalanana kadar tek tek modelden çıkarılmalıdır. Kurulan ölçüm modelinde dış yükleme değeri 0,708 eşiğinin altında olan pandemik kaygı ölçeğinin 6. maddesi, duygusal öz-yeterlilik ölçeğinin 1. maddesi ve psikolojik iyi oluş ölçeğinin 4. ve 8. maddesi modelden çıkarılmıştır. Kalan maddeler geçerlilik ve güvenilirlik 
değerlerini sağladığı için 0,708 eşiğinin biraz altında olmasına rağmen modelden çıkarılmamıştır (Hair vd., 2017). Ölçeklerin geçerliliklerini test etmek için kompozit geçerlilik (CR), Cronbach's alfa (Hair vd., 2019) ve rho_a (Dijkstra ve Henseler, 2015) değerlerinin 0,70 eşiğini geçip geçmediğine bakılmıştır. Ölçeklerin dış yükleme değerleri, güvenilirlik testleri sonuçları ve uyuşum geçerliliği (AVE) sonuçları Tablo 1'de verilmiştir.

Tablo 1: Güvenilirlik ve Uyuşum Geçerliliği

\begin{tabular}{|c|c|c|c|c|c|c|}
\hline Değişkenler & Maddeler & $\begin{array}{c}\text { Faktör } \\
\text { Yükü }\end{array}$ & Alpha & Rho_A & $\mathbf{C R}$ & AVE \\
\hline \multirow{8}{*}{$\begin{array}{c}\text { Pandemik } \\
\text { Kaygı }\end{array}$} & PK1 & 0,826 & 0,921 & 0,925 & 0,919 & 0,590 \\
\hline & PK2 & 0,853 & & & & \\
\hline & PK3 & 0,843 & & & & \\
\hline & PK4 & 0,832 & & & & \\
\hline & PK5 & 0,665 & & & & \\
\hline & PK7 & 0,650 & & & & \\
\hline & PK8 & 0,654 & & & & \\
\hline & PK9 & 0,784 & & & & \\
\hline \multirow{9}{*}{$\begin{array}{c}\text { Duygusal } \\
\text { Öz-Yeterlilik }\end{array}$} & DOY2 & 0,754 & 0,914 & 0,917 & 0,914 & 0,544 \\
\hline & DOY3 & 0,733 & & & & \\
\hline & DOY4 & 0,790 & & & & \\
\hline & DOY5 & 0,681 & & & & \\
\hline & DOY6 & 0,662 & & & & \\
\hline & DOY7 & 0,706 & & & & \\
\hline & DOY8 & 0,692 & & & & \\
\hline & DOY9 & 0,729 & & & & \\
\hline & DOY10 & 0,867 & & & & \\
\hline \multirow{6}{*}{$\begin{array}{l}\text { Psikolojik İyi } \\
\text { Oluş }\end{array}$} & PI1 & 0,706 & 0,868 & 0,869 & 0,868 & 0,523 \\
\hline & PI2 & 0,710 & & & & \\
\hline & PI3 & 0,692 & & & & \\
\hline & PI5 & 0,713 & & & & \\
\hline & PI6 & 0,751 & & & & \\
\hline & PI7 & 0,764 & & & & \\
\hline
\end{tabular}

Tablo 1'de görüldüğü üzere kurulan ölçüm modelinin yap1 geçerliliği ve güvenilirliği kabul edilebilir düzeydedir. Ölçüm modelinde son olarak ayrışım geçerliliği test edilmiştir (Hair vd., 2019). $\mathrm{Bu}$ amaçla Fornell ve Larcker kriterleri (Fornell ve Larcker, 1981) ve Heterotrait-Monotrait (HTMT) yaklaşımı (Henseler vd., 2015) benimsenmiştir. Fornell ve Larcker kriterine göre her bir değişkenin AVE değerinin karekökü diğer değişkenlerle olan korelasyonundan yüksek olmalıdır. Henseler vd. (2015) PLS tabanlı yapısal eşitlik modellemesinde ayrışım geçerliliğini sağlamak için HTMT değerinin 0,85 'den küçük olması gerektiğini belirtmiştir. Tablo 2'de kurulan ölçüm modelinin ayrışım geçerliliği sonuçları paylaşılmıştır.

Tablo 2: Ayrıșım Geçerliliği Sonuçları

\begin{tabular}{lccc}
\hline \multicolumn{1}{c}{ Değişkenler } & $\mathbf{1}$ & $\mathbf{2}$ & $\mathbf{3}$ \\
\hline Fornell ve Larcker Kriteri & & & \\
\hline 1. Duygusal Öz-Yeterlilik & $\mathbf{0 , 7 3 7 *}$ & & \\
\hline 2. Psikolojik İyi Oluş & 0,642 & $\mathbf{0 , 7 2 3} *$ & \\
\hline 3. Pandemik Kaygı & $-0,131$ & $-0,253$ & \\
\hline Heterotrait-Monotrait Ration (HTMT) & & & \\
\hline 1. Duygusal Öz-Yeterlilik & - & - & \\
\hline 2. Psikolojik İyi Oluş & 0,640 & 0,248 & - \\
\hline 3. Pandemik Kaygı & 0,130 & & \\
\hline
\end{tabular}

*Koyu renkte yazılan değerler değișkenlerin AVE değerlerinin kareköküdür. 
Tablo 2'de görüldüğü üzere değişkenler arasındaki ayrışım geçerliliği her iki kritere göre de sağlanmıştır. Böylece ölçeklerin yapı geçerliliği ve güvenilirliği açısından herhangi bir sorun olmadığına kanaat getirilmiştir ve yapısal model analizi adımına geçilmiştir.

\subsubsection{Yapisal Model}

Hipotezleri test etmek amaciyla kurulan yapısal modelde bootstrapping yöntemi uygulanmıştır. Bootstrap tekrarlama büyüklüğü ise 5000 olarak belirlenmiştir (Streukens ve LeroiWerelds, 2016). Modeldeki olası doğrudaşlık sorununu tespit etmek için VIF değerleri kontrol edilmiştir. Hair vd. (2019) yapısal modeldeki eksojen değişkenlerin VIF değerlerinin 5'ten küçük olması gerektiğini belirtmiştir. Bu kritik eşik göz önünde bulundurulurken ideal VIF değerinin 3,3'ten küçük olması yapısal modelin ölçüm hataları açısından önemli olduğuna vurgu yapmışlardır. Kurulan yapısal modeldeki VIF değerleri 2,985'ten küçük olduğu için modelde doğrudaşlık açısından herhangi bir sorun olmadığ1 görülmüştür.

Daha sonra, katsayı değerlerini önerilen t-istatistik değerine göre ölçülmüştür (Hair vd., 2017). Çift yönlü testler için yaygın olarak kullanılan kritik değerler $1,96(\mathrm{p}=\% 5)$ ve $2,57^{\prime} \mathrm{dir}(\mathrm{p}=\% 1)$. Model t-istatistik değerleri için de önerilen sınırdadır. PLS, kovaryans temelli yapısal eşitlikteki gibi iyilik uyum indeksleri üretmemektedir. Henseler vd. (2016a), PLS modelleri için uygun model uyum kriteri olarak SRMR değerinin kullanılmasını önermektedir. Buna göre 0,08'den düşük SRMR değeri modelin uyum değerini yakaladığını göstermektedir. Kurulan modelin SRMR değeri 0,069 olarak ölçülmüştür.

Yapısal modellerin açıklanmasında kullanılan en yaygın yöntem determinasyon katsayısıdır $\left(R^{2}\right)$. $R^{2}$ gerçek değerlerin ve öngörülen değerlerin korelasyonunun karesidir (Sarstedt vd., 2014). Çalışmada ayrıca çapraz doğrulanmış fazlalık için $\mathrm{Q}^{2}$ ve etki boyutu için $\mathrm{f}^{2}$ katsayıları kontrol edilmiştir. Bu bağlamda değerlendirilen hipotez testlerinin sonuçları Tablo 3'de görüldüğü gibidir.

Tablo 3: Hipotez testi sonuçları

\begin{tabular}{|c|c|c|c|c|c|c|}
\hline Yapı & $\begin{array}{c}\text { Doğrudan } \\
\text { Etki }\end{array}$ & $t$-Değeri & $p$ Değeri & PCI & $\mathbf{f}^{2}$ & Durum \\
\hline $\mathrm{H} 1: \mathrm{PK} \rightarrow \mathrm{PİO}$ & -0.167 & 4.512 & 0.000 & {$[-0.238,-0.096]$} & 0.024 & Kabul \\
\hline $\mathrm{H} 2: \mathrm{PK} \rightarrow \mathrm{DOY}$ & -0.131 & 2.991 & 0.003 & {$[-0.214,-0.048]$} & 0.026 & Kabul \\
\hline H3: DOY $\rightarrow$ PİO & 0.618 & 18.144 & 0.000 & {$[0.551,0.688]$} & 0.000 & Kabul \\
\hline KD*: Cinsiyet $\rightarrow$ PK & -0.148 & 3.777 & 0.000 & {$[-0.229,-0.069]$} & 0.043 & Kabul \\
\hline KD*: CovidTan $\rightarrow$ PK & 0.008 & 0.222 & 0.824 & {$[-0.062,0.084]$} & 0.975 & Ret \\
\hline KD*: MedeniDur $\rightarrow$ PK & -0.017 & 0.296 & 0.767 & {$[-0.134,0.095]$} & 0.954 & Ret \\
\hline KD*: ÇocukSayısı $\rightarrow$ PK & -0.112 & 1.878 & 0.061 & {$[-0.232,0.007]$} & 0.378 & Ret \\
\hline $\mathrm{KD}^{*}:$ Yaş $\rightarrow \mathrm{PK}$ & -0.008 & 0.128 & 0.898 & {$[-0.138,0.117]$} & 0.990 & Ret \\
\hline \multicolumn{7}{|l|}{ Endojen yapıların ölçümü } \\
\hline & & \multicolumn{2}{|c|}{$\mathbf{R}^{2}$} & $\mathbf{R}^{2}$ Adjusted & \multicolumn{2}{|c|}{$\mathbf{Q}^{2}$} \\
\hline Pandemik Kaygı & & \multicolumn{2}{|c|}{0.019} & 0.018 & \multicolumn{2}{|c|}{0.024} \\
\hline Duygusal Öz-Yeterlilik & & \multicolumn{2}{|c|}{0.053} & 0.047 & \multicolumn{2}{|c|}{0.009} \\
\hline Psikolojik İyi Oluş & & \multicolumn{2}{|c|}{0.442} & 0.440 & \multicolumn{2}{|c|}{0.209} \\
\hline
\end{tabular}

* KD: Kontrol Değişken

Tabloda 3'de görüldüğü üzere H1, H2 ve H3 hipotezleri kabul edilmiştir. Ayrıca kontrol değişkenlerinden cinsiyetin, pandemik kaygı üzerinde anlamlı bir etkiye sahip olduğu görülmüştür. Modelin tahmini doğruluğu ise $\mathrm{R}^{2}$ ve $\mathrm{Q}^{2}$ değerleri ile hesaplanmıştır. $\mathrm{R}^{2}$ açıklanırken 0.25 'den düşük olan değerler zayıf, 0.25-0.50 arası orta, 0.50 üstü ise güçlü olarak raporlanmaktadır. Kurulan modelde bağımlı değişken olan psikolojik iyi oluşu etkileyen değişkenlerin değeri $\mathrm{R}^{2}=\% 53$ 'dür. Buna göre değişkenlerin psikolojik iyi oluşu oldukça güçlü etkilediği söylenebilir. Çalışmada ayrıca blindfolding prosedürü ile Stone-Geisser $\mathrm{Q}^{2}$ değeri de hesaplanmıştır. Psikolojik iyi oluşun $\mathrm{Q}^{2}$ değeri 0.209'dur. 
H4 hipotezi duygusal öz-yeterliliğin pandemik kaygı ile psikolojik iyi oluş arasındaki ilişkiye aracılık edebileceğini öngörmektedir. Bu durumu tespit etmek için bootstrapping yöntemi ile Baron ve Kenny'nin (1986) standart prosedürü izlenmiştir. Sonuçlar Tablo 4'te verilmiştir.

Tablo 4: Aracı Etki Analizi

\begin{tabular}{cccccccc}
\hline Hipotez & $\begin{array}{c}\text { Toplam } \\
\text { Etki }\end{array}$ & $\boldsymbol{p}$ Değeri & $\begin{array}{c}\text { Doğrudan } \\
\text { Etki }\end{array}$ & $\boldsymbol{p}$ Değeri & $\begin{array}{c}\text { Dolaylı } \\
\text { Etki }\end{array}$ & $\boldsymbol{p}$ Değeri & $\begin{array}{c}\text { Aracılık } \\
\text { Durumu }\end{array}$ \\
\hline $\mathrm{H}_{4}: \mathrm{PK} \rightarrow$ DOY $\rightarrow$ PIO & -0.248 & 0.000 & -0.168 & 0.008 & -0.081 & 0.000 & $\begin{array}{c}\text { Kism1 } \\
\text { Arac }\end{array}$ \\
\hline
\end{tabular}

Yapılan aracıllk testi analizi sonuçları Tablo 4'te görüldüğü gibidir. Bu sonuçlara göre duygusal öz-yeterliliğin pandemik kaygı ile psikolojik iyi oluş arasındaki ilişkiye kısmi aracılık ettiği sonucuna ulaşılmıştır. Bu sonuçlara göre H4 hipotezi kabul edilmiştir. Araştırmanın final modeli Şekil 2'de verilmiştir.

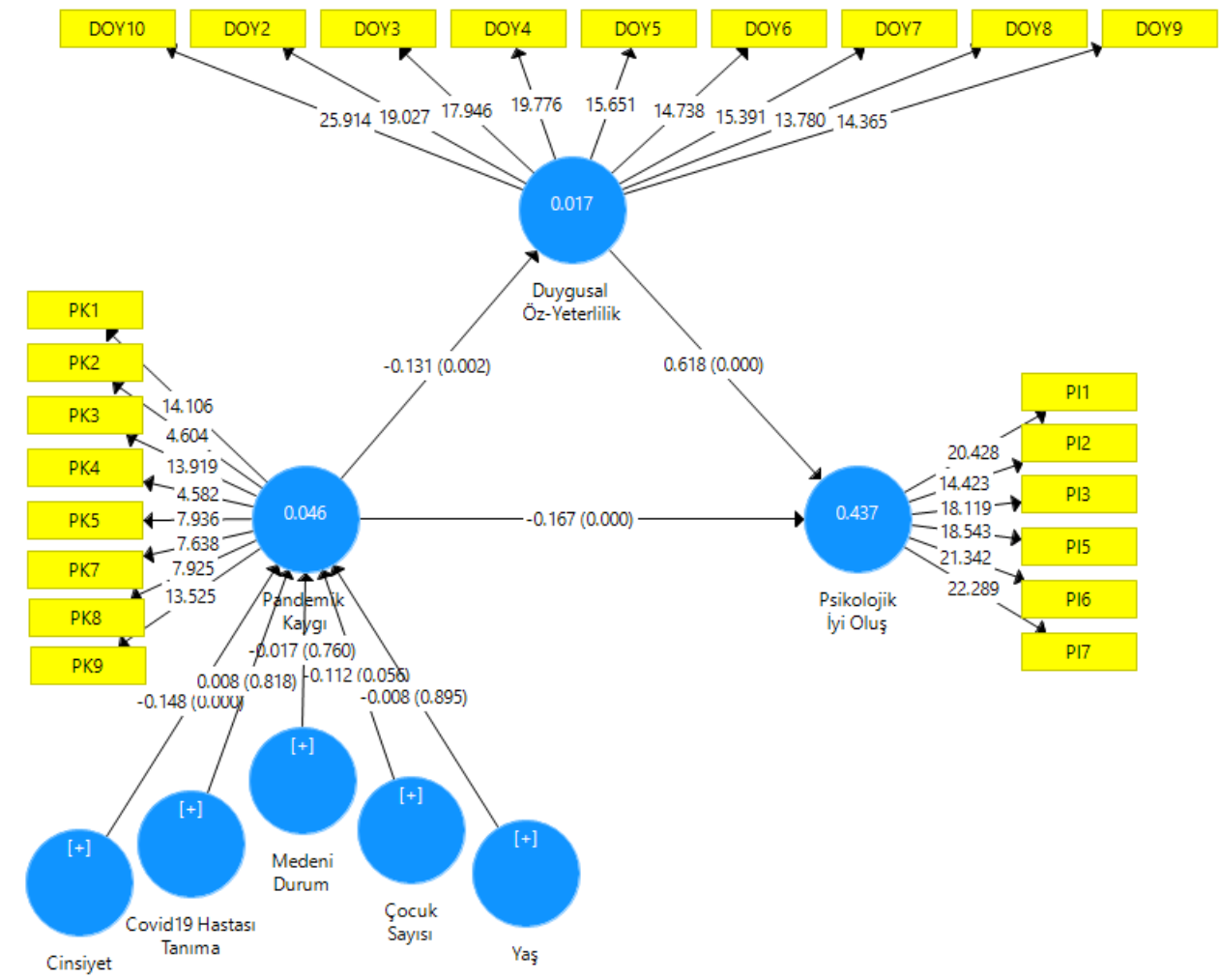

Şekil 2. Yol analizleri

\subsection{3. Çoklu Grup Analizi}

Araştırmanın temel amaçlarından bir tanesi de kaygı, iyi oluş ve öz-yeterlilik değişkenleri arasındaki ilişkinin çalışılan sektöre göre farklılaşıp farklılaşmadığını ortaya koymaktır. Bu durumu test etmek amacıyla permütasyon tabanlı çoklu grup testleri (Chin ve Dibbern, 2010) ve Henseler vd. (2009) tarafindan geliştirilen çoklu grup analizi (Multi Group Analysis-MGA) yöntemleri uygulanmıştır. $\mathrm{Bu}$ amaçla "kompozit modellerin ölçüm değişmezliği (Measurement Invariance of Composite Models-MICOM)" yaklaşımını takip edilmiştir. Bu yaklaşıma göre: (1) konfigürasyon değişmezliği, (2) bileşim değişmezliği ve (3) bileşik ortalama değerlerin ve varyansların eşitliği adımları izlenmiştir (Henseler vd., 2016b). Kamu ve özel sektördeki kompozitlerin tüm ortalamaları 
ve varyansları eşit olmadığından kısmi bir ölçüm değişmezliği oluştuğu görülmüş̧ür. Böylece ön koşul sağlanmış çoklu grup analizi yapılmıştır. Analiz sonuçları Tablo 5'teki gibidir.

Tablo 5: Kamu ve Özel Sektör Karşılaştırması

\begin{tabular}{|c|c|c|c|c|c|c|}
\hline \multirow[t]{2}{*}{ İlişki } & \multicolumn{2}{|c|}{ Yol Katsayıs1 } & \multirow{2}{*}{$\begin{array}{c}\text { Yol } \\
\text { Katsayıs1 } \\
\text { Değişimi }\end{array}$} & \multicolumn{2}{|c|}{$\begin{array}{l}P \text {-değer değişimi } \\
\text { (Tek-yön) }\end{array}$} & \multirow[t]{2}{*}{ Durum } \\
\hline & Kamu & Özel & & $\begin{array}{c}\text { Henseler } \\
\text { MGA }\end{array}$ & $\begin{array}{l}\text { Permütasyon } \\
\text { testi }\end{array}$ & \\
\hline $\mathrm{PK} \rightarrow \mathrm{PIO}$ & -0.026 & -0.224 & 0.192 & 0.028 & 0.044 & Kabul/Kabul \\
\hline $\mathrm{PK} \rightarrow \mathrm{DOZ}$ & -0.198 & -0.171 & -0.027 & 0.844 & 0.828 & Ret/Ret \\
\hline $\mathrm{DOZ} \rightarrow \mathrm{PIO}$ & 0.622 & 0.598 & 0.024 & 0.805 & 0.814 & Ret/Ret \\
\hline Cinsiyet $\rightarrow P K$ & -0.196 & -0.159 & -0.038 & 0.689 & 0.776 & Ret/Ret \\
\hline CovidTanıma $\rightarrow$ PK & -0.047 & 0.013 & -0.060 & 0.615 & 0.629 & Ret/Ret \\
\hline MedeniDurum $\rightarrow P K$ & 0.031 & -0.175 & 0.206 & 0.158 & 0.141 & Ret/Ret \\
\hline ÇocukSayısı $\rightarrow$ PK & -0.099 & 0.095 & -0.194 & 0.256 & 0.235 & Ret/Ret \\
\hline Yaş $\rightarrow P K$ & 0.026 & -0.193 & 0.218 & 0.141 & 0.153 & Ret/Ret \\
\hline
\end{tabular}

Tablo 5'te yapılan çoklu grup analizi sonuçları yer almaktadır. Analiz sonucunda pandemik kaygının psikolojik iyi oluş üzerindeki etkisi açısından her iki yönteme göre de farklılık olduğu görülmüştür. Buna göre pandemik kaygının psikolojik iyi oluş üzerindeki olumsuz etkisi kamuda yok denecek kadar az iken özel sektörde bu etki çok daha yüksektir. Başka bir deyişle pandemik kaygı özel sektör çalışanlarını daha fazla sarsmıştır. Diğer değişkenler arasında ise sektöre göre anlamlı bir farklılık olmadığ tespit edilmiştir.

\section{Tartışma ve Sonuç}

Bu çalışmada, tüm dünyayı derinden etkileyen Covid-19 pandemisinin yarattığı kaygının psikolojik iyi oluşa etkisi ve bu ilişkide duygusal öz-yeterliliğin aracı rolü, özel sektör ve kamu çalışanları nezdinde ortaya konulmaya çalışılmıştır. Bu bağlamda Türkiye genelinde çalışanlarla bir online anket çalışması gerçekleştirilmiştir. Bu çalışmaya bizi iten temel neden ise pandemi sürecinin belirsizliğidir çünkü birçok insan için en zor olan şey Covid-19'un yaratmış olduğu öngörülemezliktir. Tam olarak neyi nasıl etkiyeceğinin ve işlerin daha ne kadar kötüye gideceğinin tahmin edilememesi insanlarda kaygının artmasına etki edebilmektedir. Bu dönemde "Ya salgın bitmezse? Ya işimi kaybedersem? Ya hastalanırsam? Ya aşı bulunmazsa?" gibi sorular belirsizlik karşısında kaygılandığımızın işaretleridir. Kaygının belirsizlikten beslendiği düşünüldügünde Covid-19'un aynı zamanda tam bir kaygı kuluçkası olduğu savunulabilir.

Elde edilen bulgulara göre pandemiden ötürü çalışanlarda oluşan kaygı, onların psikolojik iyi oluşlarını olumsuz yönde etkilemektedir. Başka bir deyişle bireylerin kaygı düzeylerinin artması onları psikolojik bir çöküşe itmektedir. Araştırmanın bu bulgusu literatürdeki benzer çalışmalarla (Moreno-Rosset vd., 2016; Lawton vd., 2017; Sola-Carmona, 2013) örtüşmektedir.

Araştırmanın bir diğer bulgusu pandemik kaygının duygusal öz-yeterliliği de olumsuz yönde etkilediğidir. Bandura'ya göre (1995) pozitif ruh hali algılanan öz-yeterliliği arttırırken, umutsuz ruh hali ise azaltmaktadır. Pandemik kaygı șüphesiz negatif bir ruh halinin ürünüdür. Bu nedenle duygusal öz-yeterliliği olumsuz etkilemesi beklenilen bir durumdur. Fakat duygusal anlamda özyeterliliği yüksek bireyler çeşitli zorluklarla baş edebilmede diğerlerine nazaran daha avantajlıdır. $\mathrm{Bu}$ nedenle birçok olumsuz durumda faydalı olabileceği gibi yaşanan bu olumsuz süreçte de bireylerin öz-yeterliliği psikolojik anlamda daha sağlam bir karakter sergilemeleri açısından önemlidir.

Zimmerman (1989a), öz-yeterliliği yüksek kişilerin karşılaştığı olumsuz durumlarda gerekli eylemleri organize etme ve uygulama yeteneğinin yüksek olduğunu belirtmektedir. Öz-yeterliliğin en önemli çıktılarından biri psikolojik iyi oluştur (Adeyemo ve Adeleye, 2008). Özellikle duygusal anlamda öz-yeterliliği yüksek olan bireylerin psikolojisinin daha iyi olması beklenilmektedir 
(Cicognani, 2011). Araştırmanın sonuçları da bu iddiaları destekler niteliktedir. Duygusal özyeterliliğin psikolojik iyi oluş üzerinde olumlu bir etkiye sahip olduğu görülmüştür.

Duygusal öz-yeterlilik pozitif ruh halindeyken yükselirken tam tersi durumda azalmaktadır. Bunun yanı sıra duygusal öz-yeterliliği yüksek bireylerin olumsuz durumlarla baş edebilmesi diğerlerine göre daha kolaydır. Araştırma bulguları bu durumu desteklemektedir. Duygusal özyeterliliğin, Covid-19 sürecinin beraberinde getirdiği kaygının psikolojik olumsuz etkileriyle baş edebilmede önemli bir role sahip olduğu görülmüştür. Pandemik kaygının psikolojik iyi oluş üzerindeki etkisini tam olarak ortadan kaldıramasa da bu etkinin önemli oranda azalmasına neden olduğu tespit edilmiştir.

Ülkemizdeki kamu ile özel kesim çalışanlarının çalışma koşullarının farklılık arz ettiği gerçekliğiyle çalışma örneklemi bu iki kesimden çalışanlardan oluşturulmuştur. Böylece araştırma değişkenleri açısından karşılaştırma yapma firsatı doğmuştur. Yapılan çoklu grup analizinde pandemik kaygının psikolojik iyi oluş üzerindeki olumsuz etkisinin sektöre göre farklılaştığı tespit edilmiştir. Kamu çalışanlarının pandemik kaygı algıları psikolojik iyi oluşlarına yok denecek kadar az bir oranda etki ederken, özel sektör çalışanları açısından durum oldukça farklıdır. Özel sektör çalışanlarının kaygı algısı daha yüksek olduğu gibi psikolojik iyi oluş düzeyleri de oldukça düşüktür. Ayrıca yaşadıkları kaygı psikolojik iyi oluşlarını kamu çalışanlarına göre daha olumsuz etkilemektedir.

Hayatta, sürekli bir stres ve kaygı unsuru olduğu unutulmamalıdır. Fakat içinden geçtiğimiz bu süreçte bireylerin psikolojik durumu normal zamanlara göre daha derinden etkilenebilmektedir. Buradan hareketle çalışanların pandemik kaygı algısı ölçülmüştür. Bu bağlamda geliştirilen ölçeğin ifadeleri incelendiğinde en düşük puan ortalamasının "Korona virüs bulaşması durumunda iyi bir sağlık hizmeti alamayacağımı düşünüyorum" maddesinin olduğu görülmüştür $(M=3,25 S S=2,22)$. $\mathrm{Bu}$ durumu sağlık sistemine güven duyuluyor şeklinde yorumlamak mümkündür. Buna rağmen "Maske vb. ekipmanlara ulaşamama fikri beni kaygılandırıyor" ifadesinin ortalaması oldukça yüksektir $(M=5,18 S S=2,30)$. Sağlık sistemine güven duyulsa da bu kaygının göz önünde bulundurulmas1 gerekir. Ortalamas1 en yüksek olan ise "Aileme veya sevdiklerime korona virüs bulaşması ihtimali beni endişelendiriyor" ifadesidir $(M=6,16 S S=1,50)$. Buna göre bireyler kendilerine bulaşma ihtimalindense yakınlarına bulaşmasını daha kaygı verici bulmuştur.

Bulaşıcı hastalık sırasında, sağlık otoritelerinin sadece en kötü durumu değil, aynı zamanda daha olumlu durumları da içeren çeşitli senaryolar sunması oldukça önemlidir. Sağglık otoriteleri insanlar ile sadece 'bilinenler' (kesinlikler) hakkında iletişim kurmamalı, aynı zamanda 'bilinmeyenler' (belirsizlikler) hakkında da bilgilendirme yapmalıdırlar (Bults, vd., 2011). Bilgiye sahip olmak insanların olumlu tutum sergilemeleri ve daha düşük kaygı düzeylerine sahip olmaları üzerinde de etkiye sahiptir (Mishra vd, 2016). İnsanların kaygıdan kaçınmak için durumun ciddiyetini reddetmesi olumsuz sonuçların artması açısından bir tehlikedir. Bu durumda sağlık yetkililerinin önerilerine uymak ve bireysel olarak bilinçli hareket etmek pandemi dönemlerinde önemli davranışlardır. Bununla birlikte çalışma bulguları 1şığında birtakım öneriler sunulmuştur. Pandemi sürecinde çalışanlara, kuruluşlara ve politika yapıcılara yönelik sunulan öneriler aşağıdaki gibidir.

* Özellikle, sosyal medya ve diğer kanallardan sürekli olarak gelen hastalık hakkındaki bilgiler daha fazla kaygıya neden olabilmektedir. Bu yüzden resmi kanallar üzerinden yapılan bilgilendirmeler yalnızca olumsuz verilerden ziyade, kaygı giderici mesajlar da içermelidir.

* Tıbbi kaynaklara ve sağlık hizmetlerine erişilebilirlik daha da güçlendirilmeli ve iyileştirilmelidir. Böylece bireylerin zihninde maske vb. ekipmanlara ulaşma kaygısı ortadan kaldırılabilir.

* Yapılan analizlerde en yoğun kaygının, çalışanların yakınlarına Covid-19 bulaşması ihtimali olduğu görülmüştür. Bu durum toplumsal olarak aileye verilen önemin bir yansımas1 
niteliğindedir. Bu nedenle pandemi döneminde psikolojik olarak etkilenen bireyler ve çocuklar için pandemi sonrası bir rehabilitasyon sisteminin oluşturulması önemlidir. $\mathrm{Bu}$ sayede bireylerin kişisel, sosyal, eğitim ve mesleki durumlarının iyileşmesine katkı sunulabilir. Çevresinden göreceği iyileşme çalışanların psikolojik durumlarına da olumlu yansiyabilecektir.

* Sosyal destek sadece pandemi dönemlerinde psikolojik baskıyı azaltmakla kalmaz, aynı zamanda yardım arama yöntemlerine ilişkin tutumu da değiştirir (Cao vd., 2020). Bu sebeple pandemi dönemlerinde etkili ve sağlam sosyal desteğin varlı̆̆ vatandaşların refah düzeylerini olumlu etkileyecektir. Buradan hareketle virüsle sadece fizyolojik olarak değil de aynı zamanda sosyal psikoloji bağlamında da mücadele etmek gerekmektedir. Bu nedenle hazırlanan destek paketlerinde toplumsal psikoloji göz ardı edilmemelidir.

* Özellikle işini kaybeden bireylerin psikolojileri, pandemi dönemlerinde olumsuz yönde etkilenmektedir. $\mathrm{Bu}$ dönemlerde süreçten etkilenen bireyler toplumun, ailelerin ve çalıştıkları şirketlerin yardım ve desteğine ihtiyaç duyabilmektedir. Bu bağlamda işini kaybeden bireylerin sorunlarına yönelik çözüm odaklı ve zamanında çözümler sunulmalıdır. Unutulmamalıdır ki pandemi süreci bittiğinde piyasalar canlanıp yeniden işgücüne ihtiyaç doğacaktır. İçinden geçilen süreçte maddi kayıplar olsa da bu durum geçicidir ve süreçle baş etmede işçi çıkarmak son tercih olmalıdır.

Her çalışmada olduğu gibi bu çalışmanın da birtakım kısıtları bulunmaktadır. Öncelikle her ne kadar homojen bir örneklem oluşturulmaya çalışılmışsa da genellenebilirlik açısından sınırlılık olduğu göz önünde bulundurulmalıdır. Ayrıca kaygı, psikolojik iyi oluş ve öz-yeterlilik değişkenlerinin ölçümü sübjektif yargılara dayandığından katılımcıların yanlı cevaplar vermiş olabilecekleri bir sınırlılık olarak değerlendirilmelidir. Son olarak ölçüm araçlarının yer aldığı anket formunun online olarak uygulanmış olması da bir sinırlılıktır. Anketlerin yüz yüze uygulandığı takdirde ölçüm hatalarının minimize edilebileceği düşünülmektedir. Ayrıca gelecek çalışmalara da birtakım öneriler sunulmaktadır. Buna göre gelecek çalışmaların öz saygıyı aracı değişken olarak kullanmaları ve pandemik kaygının iş stresine olan etkisinin incelenmesi tavsiye edilmektedir.

\section{Kaynakça}

Adeyemo, D. A., \& Adeleye, A. T. (2008). Emotional intelligence, religiosity and self-efficacy as predictors of psychological well-being among secondary school adolescents in Ogbomoso, Nigeria. Europe's Journal of Psychology, 4(1), 22-31.

Akdağ Gülyüksel, F., Çankaya Cihangir, Z., (2015). Evli bireylerde psikolojik iyi oluşun yordanması. Mersin Üniversitesi Ĕ̈itim Fakültesi Dergisi, 11(3), 646-662

American Psychological Association, (2020). Anxiety. Adres: https://www.apa.org/topics/anxiety, Erişim Tarihi: 1 Mayıs 2020.

Bandura, A. (1977). Self-efficacy: Toward a unifying theory of behavioral change. Psychological Review, 84(2), 191-215.

Bandura, A. (1994). Self-efficacy. In V. S. Ramachaudran (Ed.), Encyclopedia of Human Behavior. 4, 71-81. Academic Press.

Bandura, A. (1995). Exercise of personal and collective efficacy in changing societies, in Bandura, A. (Ed.). Self-efficacy in changing societies. Cambridge University Press.

Baron, R. M., \& Kenny, D. A. (1986). The moderator-mediator variable distinction in social psychological research: Conceptual, strategic, and statistical considerations. Journal of Personality and Social Psychology, 51(6), 1173-1182. 
Baumeister, R. F., \& Heatherton, T. F. (1996). Self-regulation failure: An overview. Psychological Inquiry. 7(1), 1-15.

Bradburn, N. M. (1969). The structure of psychological well-being. Aldine Publishing Company.

Brislin, R. W. (1980). Translation and content analysis of oral and written materials. Methodology, $389-444$.

Bults, M., Beaujean, D. J., de Zwart, O., Kok, G., van Empelen, P., van Steenbergen, J. E. \& Voeten, H. A. (2011). Perceived risk, anxiety, and behavioural responses of the general public during the early phase of the Influenza A (H1N1) pandemic in the Netherlands: Results of three consecutive online surveys. BMC Public Health, 11(1), 2-13.

Cao, W., Fang, Z., Hou, G., Han, M., Xu, X., Dong, J., \& Zheng, J. (2020). The psychological impact of the COVID-19 epidemic on college students in China. Psychiatry Research, 284(2020) $112934,1-5$.

Caprara, G. V., Di Giunta, L., Eisenberg, N., Gerbino, M., Pastorelli, C., \& Tramontano, C. (2008). Assessing regulatory emotional self-efficacy in three countries. Psychological Assessment, 20(3), 227-237.

Chen, G., Gully, S. M., \& Eden, D. (2004). General self-efficacy and self-esteem: toward theoretical and empirical distinction between correlated self-evaluations. Journal of Organizational Behavior, 25(3), 375-395.

Chin, W. W., \& Dibbern, J. (2010). An introduction to a permutation based procedure for multigroup PLS analysis: Results of tests of differences on simulated data and a cross cultural analysis of the sourcing of information system services between Germany and the USA. In Handbook of partial least squares (pp. 171-193). Springer, Berlin, Heidelberg.

Cicognani, E. (2011). Coping strategies with minor stressors in adolescence: Relationships with social support, self-efficacy, and psychological well-being. Journal of Applied Social Psychology, 41(3), 559-578.

Çiçek, B., \& Karakaş, Y. E. (2020). Girişimcilerin gözünden girişimciliği etkileyen içsel ve dişsal faktörler. OPUS Uluslararası Toplum Araştırmaları Dergisi, 15(23), 125-160.

Çiçek, B., \& Kılınç, E. (2020). Teknostresin presenteizm ve işten ayrılma niyetine etkisinde dönüşümcü liderliğin aracı rolü. Business and Economics Research Journal, 11(2), 555-570.

De Beurs, E., Beekman, A. T. F., Van Balkom, A. J. L. M., Deeg, D. J. H., Van Dyck, R., \& Van Tilburg, W. (1999). Consequences of anxiety in older persons: its effect on disability, wellbeing and use of health services. Psychological Medicine, 29(3), 583-593.

Diener, E., Wirtz, D., Biswas-Diener, R., Tov, W., Kim-Prieto, C., Choi, D. W., \& Oishi, S. (2009). New measures of well-being. In Assessing well-being (pp. 247-266). Springer.

Dijkstra, T. K., \& Henseler, J. (2015). Consistent partial least squares path modeling. MIS Quarterly, 39(2), 297-316.

Easterby-Smith, M., Thorpe, R., \& Jackson, P. R. (2012). Management research. Sage Publications.

Ellison, C. W. (1983). Spiritual well-being: conceptualization and measurement. Journal of Psychology and Theology, 11(4), 330-338.

Fornell, C., \& Larcker, D. F. (1981). Structural equation models with unobservable variables and measurement error: Algebra and statistics. Journal of Marketing Research, 18(3), 382-388. 
Goldberg, D. P., \& Hillier, V. F. (1979). A scaled version of the general health questionnaire. Psychological Medicine, 9(1), 139-145.

Gove, W. R., Hughes, M. \& Briggs-Style, C. (1983). Does marriage have positive effects on the psychological well-being of the individual? Journal of Health and Social Behaviour. 24(2), 122-131.

Hair Jr, J. F., Hult, G. T. M., Ringle, C., \& Sarstedt, M. (2017). A primer on partial least squares structural equation modeling (PLS-SEM). Sage Publications.

Hair, J. F., Risher, J. J., Sarstedt, M., \& Ringle, C. M. (2019). When to use and how to report the results of PLS-SEM. European Business Review, 31(1), 2-24.

Harman, H. H. (1967). Modern factor analysis. University of Chicago Press.

Henseler, J. (2018). Partial least squares path modeling: Quo vadis?. Quality \& Quantity, 52(1), 1-8.

Henseler, J., Hubona, G., \& Ray, P. A. (2016a). Using PLS path modeling in new technology research: Updated guidelines. Industrial Management \& Data Systems, 116(1), 2-20.

Henseler, J., Ringle, C. M., \& Sarstedt, M. (2015). A new criterion for assessing discriminant validity in variance-based structural equation modeling. Journal of the Academy of Marketing Science, 43(1), 115-135.

Henseler, J., Ringle, C. M., \& Sarstedt, M. (2016b). Testing measurement invariance of composites using partial least squares. International Marketing Review, 33(3), 405-431.

Henseler, J., Ringle, C. M., \& Sinkovics, R. R. (2009). The use of partial least squares path modeling in international marketing. In New challenges to international marketing. Emerald Group Publishing Limited.

Işık, M., \& Çiçek, B. (2020). Planlı davranış teorisi perspektifinden girişimcilik niyeti üzerinde sosyal sermaye öz yeterlilik ve öz saygının rolü. Turkish Studies - Economy, 15(1), 185-206.

Jerusalem, M. \& Mittag, W. (1995). Self-efficacy in stressful life transitions, in Bandura, A. (Ed.). Self-efficacy in Changing Societies. Cambridge University Press.

Kammann, R., \& Flett, R. (1983). Affectometer 2: A scale to measure current level of general happiness. Australian Journal of Psychology, 35(2), 259-265.

Kirk, B. A., Schutte, N. S., \& Hine, D. W. (2008). Development and preliminary validation of an emotional self-efficacy scale. Personality and Individual Differences, 45(5), 432-436.

Kline, R. B. (2005). Principles and practice of structural equation modeling. Guilford Press.

Kock, N. (2015). Common method bias in PLS-SEM: A full collinearity assessment approach. International Journal of e-Collaboration, 11(4), 1-10.

Lawton, E., Brymer, E., Clough, P., \& Denovan, A. (2017). The relationship between the physical activity environment, nature relatedness, anxiety, and the psychological well-being benefits of regular exercisers. Frontiers in Psychology, 8, 1-11.

Lovibond, P. F., \& Lovibond, S. H. (1995). The structure of negative emotional states: comparison of the depression anxiety stress scales (DASS) with the beck depression and anxiety inventories. Behaviour Research and Therapy, 33(3), 335-343.

Maloney, J. C. (1990). It's hard to believe. Mind \& Language, 5(2), 122-148.

Marlatt, G. A., J. S. Baer, And L. A. Quigley, (1995). Self-efficacy and addictive behavior, in Bandura, A. (Ed.). Self-efficacy in Changing Societies. Cambridge University Press. 
Martens, M. P. (2005). The use of structural equation modeling in counseling psychology research. The Counseling Psychologist, 33(3), 269-298.

Martin, M. M., \& Rubin, R. B. (1995). A new measure of cognitive flexibility. Psychological Reports, 76(2), 623-626.

Mishra, P., Bhadauria, U. S., Dasar, P. L., Kumar, S., Lalani, A., Sarkar, P., \& Vyas, S. (2016). Knowledge, attitude and anxiety towards pandemic flu a potential bio weapon among health professionals in indore City. Przeglad Epidemiologiczny, 70(1), 41-45.

Moreno-Rosset, C., Arnal-Remón, B., Antequera-Jurado, R., \& Ramírez-Uclés, I. (2016). Anxiety and psychological wellbeing in couples in transition to parenthood. Clínica y Salud, 27(1), 29-35.

Morosanova, V., Fomina, T., \& Filippova, E. (2019). The relationship between the conscious selfregulation of schoolchildren's learning activity, their test anxiety level, and the final exam result in mathematics. Behavioral Sciences, 10(1), 16-26.

Muraven, M., \& Baumeister, R. F. (2000). Self-regulation and depletion of limited resources: Does self-control resemble a muscle? Psychological Bulletin, 126(2), 247-259.

Podsakoff, P. M., MacKenzie, S. B., Lee, J. Y., \& Podsakoff, N. P. (2003). Common method biases in behavioral research: A critical review of the literature and recommended remedies. Journal of Applied Psychology, 88(5), 879-903.

Qualter, P., Pool, L. D., Gardner, K. J., Ashley-Kot, S., Wise, A., \& Wols, A. (2015). The emotional self-efficacy scale: adaptation and validation for young adolescents. Journal of Psychoeducational Assessment, 33(1), 33-45.

Quintana, S. M., \& Maxwell, S. E. (1999). Implications of recent developments in structural equation modeling for counseling psychology. The Counseling Psychologist, 27(4), 485-527.

Ringle, C. M., Wende, S., \& Becker, J. M. (2015). SmartPLS 3. Boenningstedt: SmartPLS GmbH.

Roberts, R. E. L., \& Bengtson, V. L. (1993). Relationships with parents, self-esteem, and psychological well-being in young adulthood. Social Psychology Quarterly, 56(4), 263-277.

Rogers, S. J., \& DeBoer, D. D. (2001). Changes in wives' income: Effects on marital happiness, psychological well-being, and the risk of divorce. Journal of Marriage and Family, 63(2), 458-472.

Roothman, B., Kirsten, D. \& Wissing, M. (2003). Gender differences in aspects of psychological well-being. South African Journal of Psychology, 33(4), 212-218.

Roy, D., Tripathy, S., Kar, S. K., Sharma, N., Verma, S. K., \& Kaushal, V. (2020). Study of knowledge, attitude, anxiety \& perceived mental healthcare need in Indian population during COVID-19 pandemic. Asian Journal of Psychiatry. 102083.

Ryff, C. D. (1989). Happiness is everything, or is it? Explorations on the meaning of psychological well-being. Journal of Personality and Social Psychology, 57(6), 1069-1081.

Ryff, C. D. ve Keyes, C.L.M. (1995). The structure of psychological well-being revisited. Journal of Personality and Social Psychology, 69(4), 719- 727.

Ryff, C. D. ve Singer, B. H. (2008). Know thyself and become what you are: A eudaimonic approach to psychological well-being. Journal of Happiness Studies, 9(1), 13-39.

Ryff, C.D. (1995). Psychological well-being in adult life. Current Directions in Psychological Science, 4(4), 99-104. 
Sarstedt, M., Ringle, C. M., Henseler, J., \& Hair, J. F. (2014). On the emancipation of PLS-SEM: A commentary on Rigdon (2012). Long Range Planning, 47(3), 154-160.

Shanafelt, T., Ripp, J., \& Trockel, M. (2020). Understanding and addressing sources of anxiety among health care professionals during the COVID-19 pandemic. Journal of American Medical Association, 323(21), 2133-2134.

Shin, D. C., \& Johnson, D. M. (1978). Avowed happiness as an overall assessment of the quality of life. Social Indicators Research, 5(1-4), 475-492.

Sola-Carmona, J. J., López-Liria, R., Padilla-Góngora, D., Daza, M. T., \& Sánchez-Alcoba, M. A. (2013). Anxiety, psychological well-being and self-esteem in Spanish families with blind children. A change in psychological adjustment? Research in Developmental Disabilities, 34(6), 1886-1890.

Streukens, S., \& Leroi-Werelds, S. (2016). Bootstrapping and PLS-SEM: A step-by-step guide to get more out of your bootstrap results. European Management Journal, 34(6), 618-632.

Taha, S., Matheson, K., Cronin, T., \& Anisman, H. (2013). Intolerance of uncertainty, appraisals, coping, and anxiety: The case of the 2009 H1N1 pandemic. British Journal of Health Psychology, 19(3), 592-605.

Weston, R., \& Gore Jr., P. A. (2006). SEM 101: A brief guide to structural equation modeling. The Counseling Psychologist, 34, 719-751.

Wetzels, M., Odekerken-Schröder, G., \& Van Oppen, C. (2009). Using PLS path modeling for assessing hierarchical construct models: Guidelines and empirical illustration. MIS Quarterly, 33(1), 177-195.

Wheaton, M. G., Abramowitz, J. S., Berman, N. C., Fabricant, L. E., \& Olatunji, B. O. (2011). Psychological predictors of anxiety in response to the H1N1 (swine flu) pandemic. Cognitive Therapy and Research, 36(3), 210-218.

Williams, J., \& MacKinnon, D. P. (2008). Resampling and distribution of the product methods for testing indirect effects in complex models. Structural Equation Modeling: A Multidisciplinary Journal, 15(1), 23-51.

Yamazaki M, \& Kikkawa T. (2010), The structure of anxiety associated with avian influenza and pandemic influenza. Shinrigaku Kenkyu: The Japanese Journal of Psychology, 80(6), 476484.

Yuan, R., Xu, Q., Xia, C., Lou, C., Xie, Z., Ge, Q., \& Shao, Y. (2020). Psychological status of parents of hospitalized children during the COVID-19 epidemic in China. Psychiatry Research, 288, 112953.

Zimmerman, B. J. (1989a). A social cognitive view of self-regulated academic learning. Journal of Educational Psychology, 81(3), 329-339.

Zimmerman, B. J. (1989b). Models of self-regulated learning and academic achievement, in Zimmerman, B. J. \& Schunk, D. H. (Ed.). Self-regulated learning and academic achievement Theory. Research, and Practice. Springer.

Zimmerman, B. J. (1995). Self-efficacy and educational development, in Bandura, A. (Ed.). Selfefficacy in changing societies. Cambridge University Press.

Zimmerman, B. J. (2002). Becoming a self-regulated learner: An overview. Theory into Practice, 41(2), 64-70. 
EK-1: Pandemik Kaygı Ölçeği Ölçek Maddeleri

1- Korona virüse yakalanmaktan kaygı duyuyorum

2- Aileme veya sevdiklerime korona virüs bulaşması ihtimali beni endişelendiriyor

3- Bazen, korona virüsün asla son bulamayacağı hissine kapılıyorum

4- Korona virüs bulaşması durumunda iyi bir sağlık hizmeti alamayacağımı düşünüyorum

5- Korona virüsten ötürü rutin sağlık hizmetlerini almaktan çekiniyorum

6- Korona virüsten ötürü sosyal hayatıma eskisi gibi devam edemiyorum

7- Maske vb. ekipmanlara ulaşamama fikri beni kaygılandırıyor

8- Korona virüsle ilgili medyadaki (görsel, yazılı, sosyal) olumsuz haberler beni kaygılandırıyor

9- Sokağa çıkma yasağı olmasından/yasağın uzamasından endişeleniyorum 